\title{
Leprosy late-onset neuropathy: an uncommon presentation of leprosy
}

\author{
Neuropatia de início tardio: uma apresentação incomum da hanseníase \\ Osvaldo J.M. Nascimento, Marcos R. G. de Freitas, Tania Escada, Wilson Marques Junior, Fernando \\ Cardoso, Camila Pupe, Sandra Duraes
}

\begin{abstract}
Clinical and pathological findings in leprosy are determined by the natural host immune response to Mycobacterium leprae. We previously described cases of painful neuropathy (PN) with no concurrent cause apart from a past history of leprosy successfully treated. Four leprosy previously treated patients who developed a PN years after multidrug therapy (MDT) are reported. The mean patient age was 52.75 years (47-64). The mean time interval of the recent neuropathy from the previous MDT was 19 years (12-26). A painful multiplex neuritis or polyneuropathy were observed respectively in two cases. Electrophysiological studies disclosed a sensory axonal neuropathy in two cases. Microvasculitis with no bacilli was seen in nerve biopsy. Neuropathic symptoms were improved with prednisone. We consider these cases as being a leprosy late-onset neuropathy (LLON) form of presentation. A delayed immune reaction could explain the late appearance of LLON.
\end{abstract}

Key words: leprosy, late-onset neuropathy, nerve conduction, nerve biopsy, therapy.

RESUMO

Dados clínicos e patológicos são determinados pela resposta imune ao Mycobacterium leprae. Já haviamos descrito previamente casos de neuropatia dolorosa (ND) sem causa associada exceto história de hanseníase tratada. Relatamos agora quatro pacientes previamente tratados que desenvolveram ND anos após multidrogaterapia (MDT). A média de idade foi de 52,75 anos (47-64). 0 intervalo de tempo para o aparecimento da neuropatia recente, em relação à MDT prévia, foi de 19 anos (12-26). Neurite múltipla ou polineuropatia dolorosa foram observadas em dois casos. Estudos eletrofisiológicos revelaram ocorrência de neuropatia sensitiva axonal em dois casos. Em biópsia de nervos, foi observada microvasculite sem a presença de bacilos. Os sintomas neuropáticos melhoraram com o uso de prednisona. Consideramos esses casos como sendo a forma de apresentação de neuropatia da hanseníase de início tardio (NHIT). Reação imune tardia poderia explicar o aparecimento da NHIT.

Palavras-Chave: hanseníase, neuropatia de início tardio, condução nervosa, terapia.

Leprosy or Hansen's disease is the most common treatable peripheral neuropathy in the world ${ }^{1}$. It frequently occurs in the developing and underdeveloped countries of tropical and subtropical areas, and is infrequent in the developed countries. It usually affects the skin, the nerves, the nasal mucosa and the eyes. The clinical and the pathological findings of leprosy neuropathy are determined by the natural host immune response to Mycobacterium leprae. Leprosy should be effectively treated with multidrug therapy (MDT) before permanent nerve damage development ${ }^{2}$. Failure of early detection and early treatment often leads to severe disability in spite of the eradication of Mycobacterium at a later stage.

The most common clinical presentations are mononeuropathy, multiple mononeuropathy and polyneuropathy. In most cases, these neuropathies usually follow the skin manifestations although the neuropathy may be the only manifestation of the disease in the pure neuritic leprosy (PNL) 3 . Out of 19 PNL cases we had studied ${ }^{4}, 79 \%$ presented mononeuropathy, $10.5 \%$ multiple mononeuropathy and $10.5 \%$ polyneuropathy. The ulnar was the most frequently affected nerve. Nerve biopsy is essential for a definite diagnostic of PNL.

In 1992, we described cases of painful neuropathy with no concurrent cause apart from a past history of leprosy successfully treated. The nerve biopsy was characterized by inflammatory infiltrates, severe fiber loss and no bacilli ${ }^{5}$. These cases were reported as "late painful neuropathy years after leprosy treatment", calling attention for this late manifestation of leprosy neuropathy. An immune reaction due to the persistence of the bacilli antigen associated to ischemia was then considered as the possible pathogenesis ${ }^{5}$.

Department of Neurology and Neurology/Neuroscience Clinical Research Sub-Unit, Fluminense Federal University (UFF), Rio de Janeiro RJ, Brazil.

Correspondence: Osvaldo J. M. Nascimento; Rua Siqueira Campos 53/1204; 22031-071 Rio de Janeiro RJ - Brasil; E-mail: osvaldo_nascimento@hotmail.com Support: FINEP, MCTI-CNPq

Conflict of interest: There is no conflict of interest to declare.

Received 09 October 2011; Received in final form 24 January 2012; Accepted 01 February 2012 
Table. Clinical, eletrophysiological and hysthological features of LLON patients.

\begin{tabular}{|c|c|c|c|c|c|c|c|}
\hline Patient & Age & Gender & TAM (years)/ TNS (mo.) & Symptoms & Neurological exam & EDX & $\mathrm{BX}$ \\
\hline 1 & 51 & M & $15 / 10$ & $\begin{array}{l}\text { Progressive pain in } \\
D L \text { and feet, } L>R\end{array}$ & $\begin{array}{l}\text { Leg refl. } \varnothing ; \text { DL pin- } \\
\text { temp anesthesia }\end{array}$ & N MNCV; Sural $\varnothing$ & $\begin{array}{c}\text { MNCL/ vessels; } \\
\downarrow \downarrow \text { MFD, fibrosis NB }\end{array}$ \\
\hline 2 & 64 & M & 23/18 & $\begin{array}{l}\text { Pain in L hand and } \\
\text { arm, and feet }\end{array}$ & $\begin{array}{l}\text { L hand interosseus } \\
\text { m. atrophy; L arm } \\
\text { and legs refl } \varnothing ; \text { ulnar } \\
\text { and DL pin-temp } \\
\text { anesthesia }\end{array}$ & $\begin{array}{l}\text { Ulnar MNCV and } \\
\text { CMAP } \downarrow ; \text { SNCV: } \\
\text { L ulnar and sural } \\
\varnothing ; \text { interosseus m. } \\
\text { denervation }\end{array}$ & $\begin{array}{c}\text { MNCL/ vessels; } \\
\downarrow \downarrow \text { MFD, fibrosis NB }\end{array}$ \\
\hline 3 & 47 & $\mathrm{~F}$ & $12 / 8$ & Burning feet & $\begin{array}{l}\text { Knee refl. } \boldsymbol{\Downarrow} \text {; ankle } \\
\varnothing ; \text { DL pin-temp } \\
\text { anesthesia }\end{array}$ & $\mathrm{N}$ & $\begin{array}{c}\text { MNCL/ vessels; } \\
\downarrow \downarrow \downarrow M F D, \text { Fibrosis NB }\end{array}$ \\
\hline 4 & 49 & M & $26 / 12$ & $\begin{array}{l}\text { Progressive pain in } \\
\text { DL and feet }\end{array}$ & $\begin{array}{l}\text { Refl. N; DL pin-temp } \\
\text { hypoesthesia }\end{array}$ & N & $\begin{array}{c}\text { MNCL/ vessels; } \\
\downarrow \downarrow \text { MFD, Fibrosis NB }\end{array}$ \\
\hline
\end{tabular}

LLON: leprosy late-onset neuropathy; TAM: time elapsed after multidrug therapy; TNS: time duration of leprous late onset neuropathy symptoms; EDX: electrodiagnostic - conduction study; BX: nerve biopsy; DL: distal legs; L: left side; R: right side; refl.: tendon reflex; pin-temp: pinprick and temperature sensations; $\varnothing$ : abolished; $\boldsymbol{\Downarrow}$ :reduced; m.: muscle; NCS: nerve conduction studies; MNCV: motor nerve conduction velocity; SNCV: sensory nerve conduction velocity; N: normal; /:surrounding; $\downarrow \downarrow$ :severely reduced; MNCL: mononuclear cells infiltrates; NB: no bacilli.

In the present report, our objective was to describe the clinical, neurophysiological and hystopathological characteristics, and treatment response in four late-onset neuropathy cases appeared after previous leprosy treatment.

\section{METHODS}

Four patients previously treated with MDT for skin leprosy (lepromatous leprosy clinical form) and living in a nonendemic area were sent to neurological evaluation by dermatologists due to recent onset neuropathy. They all had been excluded for an active leprosy infection or reinfection (Table). Neurological and dermatological examination was performed. Electrophysiological examination with standard techniques and sural nerve biopsies were conducted. The material was included in paraffin for routine staining, and Araldite for semithin sections. Wade-Fite acid-fast stain for leprosy bacilli was performed. Glucose intolerance, diabetes, other metabolic or endocrine disorders, vascular or collagen diseases associated or not with vasculitis, HIV, HTLV-1/2, HBV and HCV-virus infections, cancer and other causes of neuropathies were ruled out, clinically and laboratorially.

\section{RESULTS}

Table shows the clinical features of all four patients. The mean age was 52.75 years (47-64). The mean time of the recent installed neuropathic symptoms appearance after MDT treatment was 19 years (12-26), and the mean time of symptoms duration was 12 months (8-18). The neuropathy had a multifocal distribution in cases 1 and 2, with nerve enlargements (ulnar and fibular nerves), and was symmetric in cases 3 and 4 . A predominant small fiber involvement was observed in all cases, and neuropathic pain was the most important complaining. Electrophysiological test was consistent with

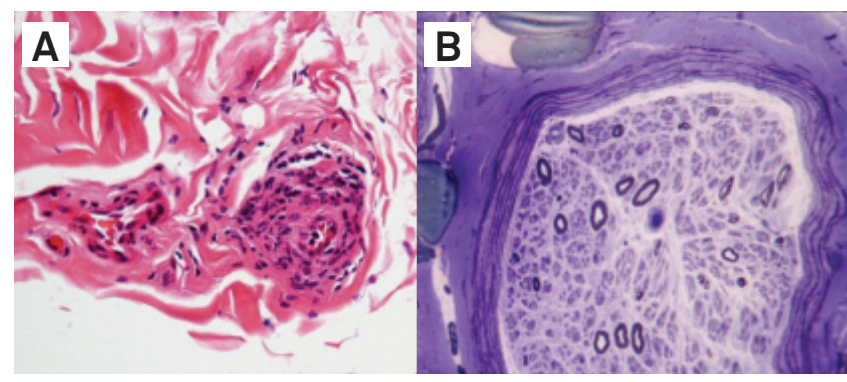

Fig. Sural nerve biopsy. (A) Case 1 - an inflammatory mononuclear cell infiltrate surrounding an epineurial vessels (microvasculitis) can be seen. H\&E, x 200; (B) Case 2 semithin section showing a severely decreased myelinated fiber density. Toluidine blue $\times 400$.

a predominantly axonal and sensory neuropathy in case 2 , was exclusively sensory in case 1 and was normal in the remaining cases. Nerve biopsies of all four cases showed the presence of inflammatory mononuclear cells infiltrates, mainly surrounding epineurial vessels, suggesting microvasculitis (Fig A). Neoangiogenesis was seen in all nerve samples. Semithin sections revealed a severely decreased myelinated fiber density, mainly affecting the small nerve fibers, comprising an inflammatory axonal neuropathy (Fig B). Wade staining for bacilli identification was negative in all nerves. Treatment with prednisone $(1 \mathrm{mg} / \mathrm{kg} /$ day progressively tapered to $20 \mathrm{mg}$ /day) was associated to great improvement of the neuropathic pain.

\section{DISCUSSION}

Type 1 reaction or reversal reaction $(\mathrm{RR})$ is a late cellular hypersensibility reaction type IV, which usually appears during the first months of treatment. Neuritis is an important feature. Preexistent skin lesions become steadily more swelled up, reddened and even ulcerate. Fever, malaise and anorexia may be present. Facial swelling, as well as swelling 
of the legs and upper limbs, is characteristic ${ }^{6}$. The type 2 reaction or erithema nodosum leprosum (ENL) is an acute inflammatory condition involving a TNF-alfa and immune complex mediated immune response with infiltration of Th2cells ${ }^{7}$. Nodules and painful raised red papules are characteristic. Accompanying these nodules there are neuritis, uveitis, iridocyclitis, episcleritis, arthritis, dactilitis, lympohadenitis and orquitis. Fever, prostration, anorexia, as well as other constitutional symptoms, are frequent ${ }^{7}$. None of these signs or symptoms was present in our patients.

Relapse in leprosy is a reoccurrence of the disease at any time after the completion of MDT. There are different causes of relapses: an inadequate MDT due to misclassification of the disease, a premature stop of MDT or a poor compliance. Sometimes, even with adequate MDT, the relapse is due to multiplication of persistent bacilli or drug resistance. The relapses may be in the form of late reversal reaction or due to reinfection ${ }^{8}$. Persistence of M. leprae antigen in local lesions after regular multiple drug therapy (MDT) is an important risk factor for late reactions ${ }^{9}$. Occasionally, some patients develop delayed nerve impairment months or year after MDT, which could not be explained by relapses or reactions. They may have a chronic and slowly progressive form of multiple mononeuropathy or polyneuropathy ${ }^{5}$, and there is no activity of leprosy. We consider these cases of late painful neuropathy appearing many years after leprosy treatment as being a leprosy lateonset neuropathy (LLON) form of presentation. Our patients presented this modality of neuropathy. There was no clinical or nerve biopsy findings suggestive of leprosy reinfection. The microvasculitis and the presence of neoangiogenesis support a possible role of an ischemic process. A delayed immune reaction ${ }^{5,10}$ could explain the late appearance of LLON.

In conclusion, this modality of neuropathy encompass clinically the late painful cases and possibly others non-painful which appear late after leprosy treatment. Electrophysiological findings support a more severe compromise of the small fibers, and immunosuppressive treatment with prednisone or methylprednisolone seems to be efficacious. A better understanding of LLON clinical features and physiopathology is needed for its good management.

\section{References}

1. Said G. Infectious neuropathies. Neurol Clin 2007;25:115-137.

2. Talwar S, Jha PK, Tiwari VD. Neuritic leprosy: epidemiology and therapeutic responsiviness. Lepr Rev 1992;63:263-268.

3. Freitas MRG, Nascimento OJM, Quaglino EAM, Oliveira A, Hahn MD. Small-fiber polyneuropathy in leprosy without skin changes: study of 17 cases. Arq Neuropsiquiatr 2003;61:542-546.

4. JardimMR,ChimelliL,FariaSCR,etal.Clinical,electroneuromyographic and morphological studies of pure neural leprosy in a Brazilian referral center. Lepr Rev 2004;75:242-253.

5. Nascimento OJM, Freitas MRG, Escada TM, et al. Late progressive painful neuropathy appearingyears after long-treated leprosy. In: $11^{\text {th }}$ International meeting on neuromuscular diseases. Marseille, France; 1992:151.
6. Sabin TD, Swift TR, Jacobson RR. Leprosy. In: Dyck PJ, Thomas PK (Eds). Peripheral neuropathy. $4^{\text {th }}$ ed. Philadelphia: Elseviers Saunders; 2005:2081-2105.

7. Van Veen NHJ, Nicholls PG, Smith WC, Richardus JH. Corticosteroids for treating the nerve damage in leprosy. A Cochrane review. Lepr Rev 2008;79:361-387.

8. Kar HK, Sharma P. New lesions after MDT in PB and MB leprosy: a report of 28 cases. Indian J Lepr 2008;80:247-255.

9. Harboe M, Aseffa A, Leekassa R. Challenges presented by nerve damage in leprosy. Lepr Rev 2005;76:5-13.

10. Rosemberg NR, Faber WR, Vermeulen M. Unexplained delayed nerve impairment in leprosy after treatment. Lepr Rev 2003;74:357-365. 